\title{
CO-INFECTION OF BOVINE PAPULAR STOMATITIS VIRUS, ROTAVIRUS AND CRYPTOSPORIDIUM SPP. IN A CALF
}

\author{
EROKSUZ Yesari ${ }^{1 *}$, TIMURKAN Mehmet Özkan², ABAYLI Hasan², \\ INCILI Canan Akdeniz ${ }^{1}$, KARABULUT Burak ${ }^{1}$, EROKSUZ Hatice ${ }^{1}$ \\ ${ }^{1}$ Department of Pathology, Faculty of Veterinary Medicine, Firat University, Elazig, Turkey; \\ ${ }^{2}$ Department of Virology, Faculty of Veterinary Medicine, Ataturk University, Erzurum, Turkey; \\ ${ }^{3}$ Department of Virology, Faculty of Veterinary Medicine, Firat University, Elazig, Turkey
}

(Received 09 April, Accepted 25 September 2020)

\begin{abstract}
Concurrent occurence of bovine papular stomatitis, rotavirus infection and cryptosporidiosis was diagnosed postmortem in a 7-days-old calf from a farm containing 65 calves of different ages. Multifocal papular stomatitis and rumenitis were present on necropsy. While polymerase chain reaction analysis revealed rotavirus and papular stomatitis virus infections; bovine viral diarrhea, foot and mouth disease, bovine papilloma virus and coronavirus could not be detected. Overall; concurrent coinfection with bovine papular stomatitis virus, rotavirus and cryptosporidium spp. was reported for the first time.
\end{abstract}

Key words: Bovine papular stomatitis, rotavirus, cryptosporidiosis.

\section{INTRODUCTION}

Bovine papular stomatitis (BPS) is a disease caused by bovine papular stomatitis virus (BPSV) belonging to the family of Poxviridae, genus Parapoxvirus. This virus is closely related to the parapoxviruses causing contagious ecthyma and pseudocowpox. Transmission of the virus likely occurs by direct contact between infected animals, with no requirement for virus reservoirs other than cattle or vectors. Detection of viral DNA in a large number of healthy animals suggests that subclinically infected animals might be the reservoir of the virus. DNA viruses in the Poxviridae family show epitheliotropism causing cutaneous and systemic infections in wild and domestic animals, poultry and humans. After skin invasion, the virus enters the bloodstream causing a primary viremia followed by a secondary viremia leading to the spread of the virus back to the skin and other target organs. Poxviruses induce degenerative changes by their proliferation in endotelial cells or in the epithelium leading to the formation of typical lesions [1,2].

*Corresponding author: e-mail: yeroksuz@firat.edu.tr 
This report describes the diagnostic features of BPSV infection concurrent with rotavirus and cryptosporididosis in a 7 days-old calf.

\section{CASE PRESENTATION}

A calf from a feedlot farm was submitted to the Veterinary Pathology Laboratory of Firat University, School of Veterinary Medicine. The calf was a male 7 day-old BlackSwiss calf. There were a total of 65 calves and 112 cows, including 15 dead and 4 having clinical signs characterized by loss of appetite, diarrhea, and papules on the oral mucosa and muzzle. The adult cows did not show clinical signs of illness. At necropsy, the most prominent change was multifocal to coalescing circular erythematose macules or papular eruptions in the muzzle, gingival and buccal mucosa, palatine and ruminal mucosa. Ruminal macules were co-existent with locally extensive hyperemia and edema. Erythematous macules were $2-3 \mathrm{~cm}$ in diameter and surrounded by a hyperemic zone (Fig. 1). After necropsy, tissue samples from the oral mucosa, forestomach, abomasum, liver, lungs, spleen, pancreas, brain, small and large intestines, heart, and kidneys were fixed in 10\% neutral formalin, processed routinely, embedded in paraffin and 4-5 $\mu \mathrm{m}$ sections were obtained and stained with hematoxylin and eosine (H\&E). Selected tissue sections were stained with Brown-Brenn's stain (B\&B), and Page-Green method for inclusion bodies. Immunohistochemistry (avidin-biotin immunoperoxidase method) was performed utilizing monoclonal antibodies to vascular endothelial growth factor (VEGF).
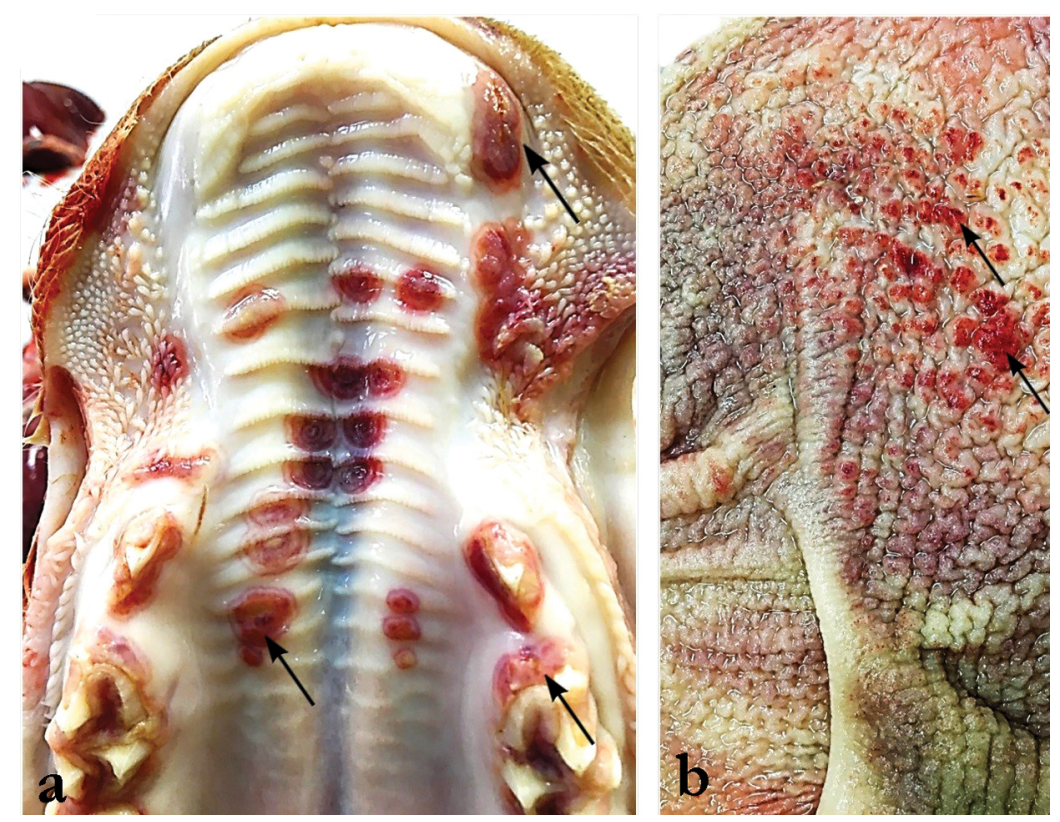

Figure 1. Erythematous and proliferative papules in the palatine, gingival (A) and ruminal mucosa (B) 

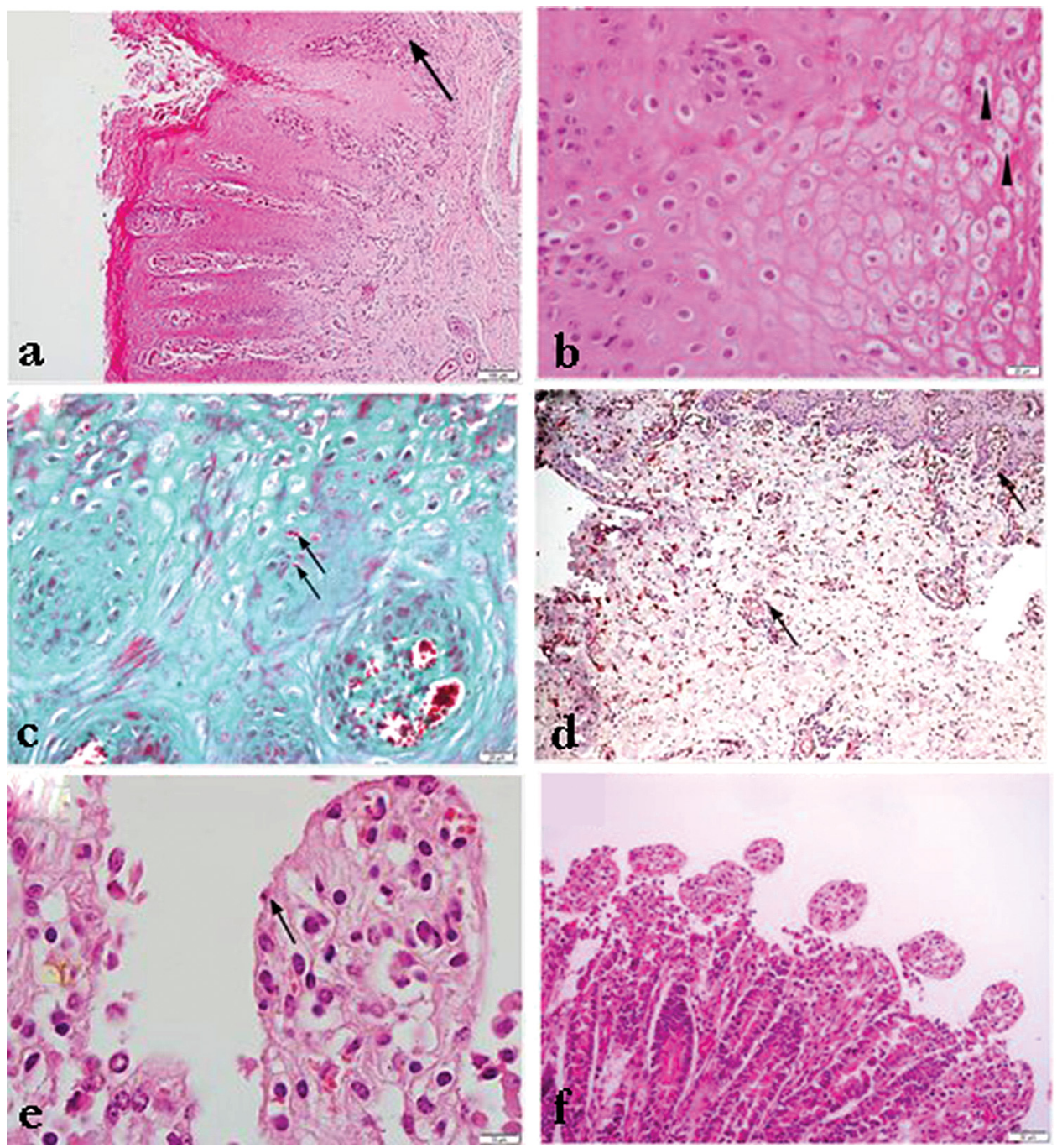

Figure 2. Epitelial hyperplasia, parakeratotic hyperkeratosis, inflammatory reaction by macrophages, eosinophils and lymphocytes (arrow) (A). Hydropic degeneration and intracytoplasmic eosinophilic inclusion bodies (arrow heads) (B). Intracytoplasmic inclusions, Page-Green method (arrows) (C). Diffuse VEGF expression in oral mucosal epithelium and lamina propria, immunperoxidase staining (arrows) (D). The villus surface is covered with cuboidal, weakly differentiated epithelium (arrow) (E). Atrophic villi with indistinct microvillous edges $\mathbf{( F )}$.

There was a focally extensive epithelial hyperplasia, rete ridges formations, acantholysis and parakeratotic hyperkeratosis in the palatine (Fig-2A), glossal and ruminal mucosa. The lamina propria and submucosa were edematous and congested with mild to moderate infiltration of macrophages and lymphocytes (Fig-2A). There was hydropic degeneration in the stratum spinosum, whereas basal epithelial cells were intact. Affected cells contained intracytoplasmic eosinophilic inclusion bodies (Fig- 
2B-C). VEGF staining showed intense positive immunoreactivity in the epithelial and mesenchymal cells.

Similar changes including macules, edema and congestion were present in the mucosa of the ruminal dorsal sac. In the small intestine, the mucosal surface was covered with cuboidal, less differentiated epithelium, with indistinct microvillous edges and atrophic villi. (Fig-2E-F). Examination of feces stained by Ziehl Neelsen method indicated the presence of cryptosporidium oocysts. Furthermore, the commercial rapid test (Speed ${ }^{\circ}$ V-DIAR 4) on the stool was positive for Cryptosporidium spp.

The samples from the oral mucosa and intestinal tissues were homogenized with phosphate-buffered saline (PBS, $\mathrm{pH}$ 7.2). The homogenate was used in DNA and RNA isolates. DNA and RNA isolation was performed in accordance with the instructions for use for Allprep DNA / RNA mini-kit (Qiagen, Germany). For the purposes of synthesizing the complementary DNA, a mixture of total RNA $(1 \mu \mathrm{g})$ random hexamer primer $(100 \mathrm{ng})$ and M-MLV reverse transcriptase enzyme (200 U) was incubated at $25^{\circ} \mathrm{C}$ for 10 minutes and then at $37^{\circ} \mathrm{C}$ for 50 minutes. cDNA and DNA were used as templates in the PCR stage. For the diagnosis of panpestivirus (BVDV) (p324-326) [3], vesicular stomatitis (VSV) [4], bovine papilloma virus type2 (BPV-2) (P1-2-3) [5], bovine papular stomatitis virus (BPSV) (PPP1-3-4) [6], foot and mouth disease virus (FMDV) (2BF-2BR) [7], rotavirus (BRV) [8] and coronavirus (BCV) [9] reference primers and PCR protocols were used. The obtained amplicons were analyzed by electrophoresis (110V / $40 \mathrm{~min})$ in 1.5\% (w/v) agarose gel stained with ethidium bromide (EtBr). The expected amplicons for the Pan-parapox B2L gene were sequenced in the Macrogen laboratory. At this stage, the ABI 3730XL Sanger sequencing device (Applied Biosystems, Foster City, CA) and the BigDye Terminator v3.1 Cycle Sequencing kit were used. (Applied Biosystems, Foster City, CA). The bidirectional sequence data aligned with the ClustalW program was verified by BLAST software. The partial genomic sequence of BPSV strain BPSV01-TR-Elzg-2017 has been submitted to Genbank (MN887533). After the alignment of the different parapoxvirus strains in the Genbank with Mega X software, phylogenetic analysis (Fig4) was performed by using the Maximum-likelihood method algorithm (bootstrap, 1000 replicates) with Tamura Nei model.

It detected amplification products of the expected size (590 bp for PPP1-4 primer pairs; 235 bp for PPP3-4 primer pairs, Fig-3A) as a result of semi-nested PCR for bovine papular stomatitis virus. Also amplicon size of 379 bp was positive for bovine rotavirus (Fig-3B). According to RT-PCR or PCR results, we did not detect RNA of pestivirus, FMDV, BCV and VSV, or DNA of BPV-2 in clinical samples.

There are 3 previous reports related to BPSV in Turkey up to date. These reports contain histopathological findings and molecular findings [10,11,12]. The present report comprised both the pathological and molecular findings. Earlier reports showed that immunosuppression caused by BVD, antilymphocyte globulin treatment, and sham thymectomy enhances the prevalence of papular stomatitis [13] and BPSV infection was reported together with BVDV [14], coccidiosis [15], cryptosporidiosis [12], pseudocowpox [16] and papilloma virus infection [17]. 

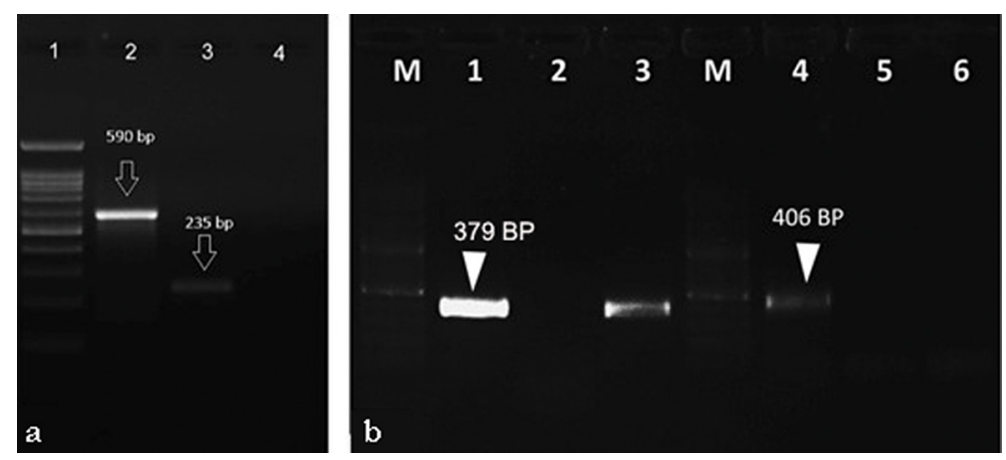

Figure 3. Agarose gel electrophoresis (\%1.5) of the PCR amplification products derived from clinical sample. lane 1, $100 \mathrm{bp}$ DNA ladder lane 2, first round PCR product lane 3, second round PCR product (semi-nested PCR), lane 4, negative control (A) PCR results for Rotavirus (Lane 1-2-3) and Coronavirus (Lane 4-5-6). M: Marker (100 bp DNA ladder, Thermo Scientific, Germany), Lane 3 and 6: Intestinal sample, Lane 1: Rotavirus positive control, Lane 4: Coronavirus positive control, Lane 2 and 5: Negative control, (B).

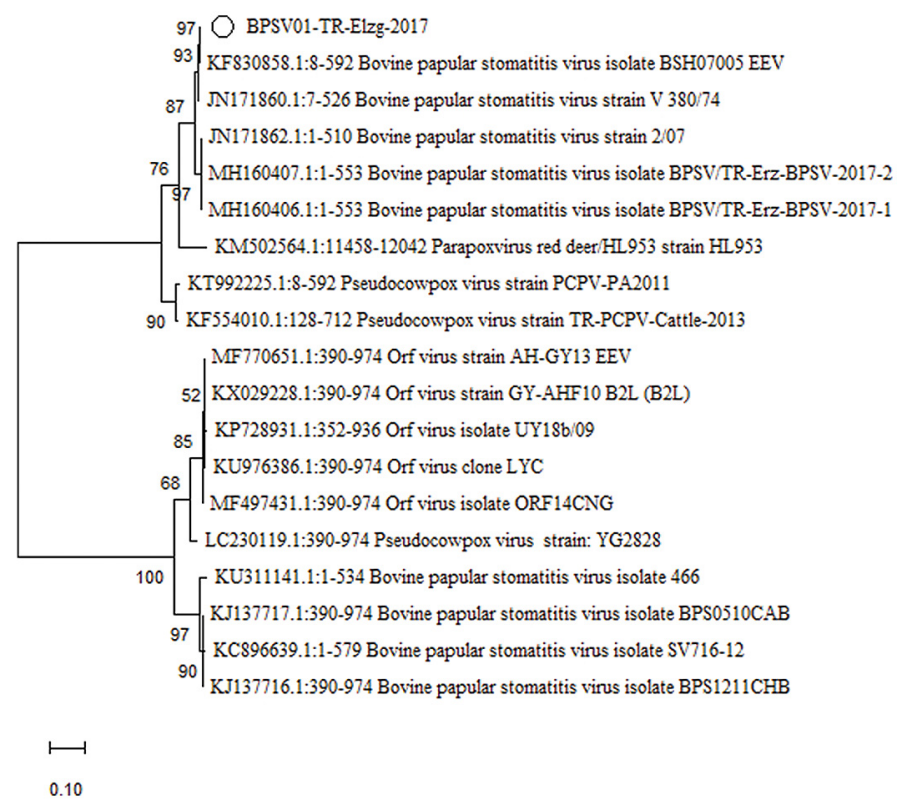

Figure 4. Phylogenetic analysis based on the pan-parapoxviruses partial B2L gene nucleotide sequences. Phylogenetic tree was performed by using the Maximum-likelihood method algorithm (bootstrap, 1000 replicates) with Tamura Nei model

In the present report BVDV infection was not detected. However, rotavirus infection which has not been previously reported together with bovine papular stomatitis, was identified in a calf. Although the immunosuppressive effects of rotavirus are not known, rotavirus cause villous atrophy, maldigestion and malabsorption by inducing the destruction and loss of enterocytes. All these processes might cause stress and secondary immunosuppression. 
According to the BLAST analysis result, the nucleotide sequence of the BPSV01TR-Elzg-2017 strain in the present report has more than $99.0 \%$ similarity to the Bangladesh isolate (BSH07005, accession number: KF830858.1) [18] and Brazilian isolate [19] (SV716-12 accession number: KC896639.1). Interestingly Turkish BPSV strains (BPSV/TR-Erzurum-BPSV-2017-1, 2 accession number: MH160406, MH160407) which were detected in 2017 in Erzurum had the similarity ratio $96.56 \%$ and $96.74 \%$, respectively [13].

Extensive VEGF expression in epithelial and stromal tissues in the present report comply with an earlier theory that a viral-encoded vascular endothelial growth factor (VEGF) induces vascularization and dermal oedema through VEGF receptor-2 [20].

In conclusion; triad of cryptosporidiosis, rotavirus and BPSV infection was reported for the first time.

\section{Authors' contributions}

$\mathrm{KB}$ and AIC carried out necropsy and histopathological examination. AH and TMO carried out the molecular virological studies. EY and EH carried out the draft the manuscript. All authors read and approved the final manuscript.

\section{Declaration of conflicting interests}

The author(s) declared no potential conflicts of interest with respect to the research, authorship, and/or publication of this article.

\section{REFERENCES}

1. McGavin MD, Zachaary JF. Pathologic Basis of Veterinary Diseases, 4th edition. MosbyElsevier, St Louis, Missouri, 1476 pp. 2007. ISBN 0-3230-2870-5

2. Grant M. Jubb, Kennedy \& Palmer's Pathology of Domestic Animals, 5th edition. Saunders Ltd. Philadelphia, 2340 pp. 2007.

3. Bulut H, Sozdutmaz I, Pestil Z, Abayli H, Sait A, Cevik A. High prevalence of bovine viral diarrhea virus-1 in sheep abortion samples with pestivirus infection in Turkey: Pak. Vet. J. 2018, 38 (1): 71-75.

4. Lung O, Furukawa-Stoffer T, Burton Hughes K, Pasick J, King DP, Hodko D. Multiplex RT-PCR and Automated Microarray for Detection of Eight Bovine Viruses: Transbound. Emerg. Dis. 2017, 64 (6): 1929-1934.

5. Wosiacki SR, Barreiro MA, Alfieri AF, Alfieri AA. Semi-nested PCR for detection and typing of bovine Papillomavirus type 2 in urinary bladder and whole blood from cattle with enzootic haematuria: J. Virol Methods 2005, 126 (1-2): 215-9.

6. Inoshima Y, Morooka A, Sentsui H. Detection and diagnosis of parapoxvirus by the polymerase chain reaction: J Virol Methods 2000, 84: 201-208. 
7. Karapinar T, Dabak DO, Kuloglu T, Bulut H. High cardiac troponin I plasma concentration in a calf with myocarditis: Can. Vet. J. 2010, 51(4): 397-399.

8. Timurkan MÖ, Alkan F. Identification of rotavirus A strains in small ruminants: first detection of G8P[1] genotypes in sheep in Turkey: Arch. Virol. 2020, 165: 425-431.

9. Timurkan MÖ, Aydın H, Belen S. The detection and molecular characterization of bovine respiratory coronavirus infection by RT-PCR in Erzurum: Atatürk Üniversitesi Vet. Bil. Derg. 2015, 10 (3), 186-192.

10. Ozdemir O, Ortatatlı M, Hatipoglu F, Erer H, Yavuz O. A Case of Papular Stomatitis in aof Seventy-Five Day Old Calf: IV. National Veterinary Pathology Congress, (International Participation) 29 October-2 November 2008, Kemer / Antalya.

11. Senturk S, Catık S, Temizel EM, Ozyigit O. Outbreak of bovine papular stomatitis with concurrent cryptosporidiosis in a dairy herd in Turkey: Bulg. J. Vet. Med. 2016, 19: No 1, 78-83.

12. Timurkan MÖ, Kırbaş AH, Yanari E. First molecular characterization of bovine papular stomatitis virus in Turkey: ATAVET 1. International Student Congress, 04-06 December 2018, ERZURUM / TURKEY

13. Huang T, Tulman ER, Diel DG et al. Coinfection with multiple strains of bovine papular stomatitis virus: Arch. Virol. 2015, 160 (6): 1527-1532.

14. Bohac JG, Yates WDG. Concurrent bovine virus diarrhea and bovine papular stomatitis infection in a calf: Can. Vet. J. 1980, 21: 310-313.

15. Seifi HA, Movassaghi AR, Mohri M, Rad M, Aslani MR, Parand A, Razmi GH. Concurrent coccidiosis and bovine papular stomatitis infection in calves: J. Appl. Anim. 2000, 18: 103108.

16. Matsumoto H, Setoyama H, Matsuura Y et al. Sequential detection of pseudocowpox virus and bovine papular stomatitis virus in a calf in Japan: J. Vet. Med. Sci. 2019, 81 (3): 440-443.

17. Zhu W, Haga T, Yuan D et al. Coinfection of a lingual lesion with bovine papular stomatitis virus and bovine papillomavirus: Arch. Virol. 2019, 164 (5): 1441-1444.

18. Lederman E, Khan SU, Luby S, Zhao H, Braden Z, Gao J, Karem K, Damon I, Reynolds M, Li Y. Zoonotic parapoxviruses detected in symptomatic cattle in Bangladesh: BMC Res. Notes 2014, 7: 816.

19. de Sant'Ana, F J, Rabelo RE, Vulcani VA, Cargnelutti JF, Flores EF. Bovine papular stomatitis affecting dairy cows and milkers in midwestern Brazil: J. Vet. Diagn. Invest. 2012, 24 (2), 442-445.

20. Inder MK, Ueda N, Mercer AA, Fleming SB, Wise LM. Bovine papular stomatitis virus encodes a functionally distinct VEGF that binds both VEGFR-1 and VEGFR-2: J. Gen Virol. 2007, 88 (Pt 3): 781-791. 


\section{KOINFEKCIJA TELADI VIRUSOM PAPULARNOG STOMATITISA GOVEDA, ROTAVIRUSOM I CRYPTOSPORIDIUM SPP.}

EROKSUZ Yesari, TIMURKAN Mehmet Özkan’ ABAYLI Hasan, INCILI Canan Akdeniz, KARABULUT Burak, EROKSUZ Hatice

Postmortalno je dijagnostikovana infekcija virusom papuloznog stomatitisa, rotavirusna infekcija kao i kriptosporidioza kod teleta starog 7 dana, na farmi sa 65 teladi različitog uzrasta. Prilikom obdukcije, uočene su multifokalne lezije karakteristične za papulozni stomatitis kao i rumenitis. Testom lančane reakcije polimeraze (PCR) dokazano je prisustvo rotavirusa i virusa izazivača papuloznog stomatitisa, pri čemu nisu dokazani virusi izazivači bovine virusne dijareje, slinavke i šapa, papilomatoze i koronavirusne infekcije. Uopšteno, ovim je po prvi put je prikazan slučaj koinfekcije virusom izazivačem papuloznog stomatitisa, rotavirusne infekcije i infekcija sa Cryptosporidium spp. 